\title{
MICROBIAL COMPOSITION OF PROCESSED FOODS
}

\author{
*ALI I ${ }^{1},{ }^{* I D R E E S ~} \mathrm{~N}^{2}$, *SIDDQUE $\mathrm{A}^{2}$, SHAH KH ${ }^{3}$, AHMAD $\mathbf{R}^{2}$, ALI $\mathrm{A}^{2}$, FATEH $\mathrm{A}^{2}$ \\ ${ }^{I}$ Department of Microbiology and Molecular Genetics, University of Okra, Okra, Pakistan \\ ${ }^{2}$ Institute of Molecular Biology and Biotechnology, The University of Lahore, Lahore, Pakistan \\ ${ }^{3}$ Department of Life Science, University of Management \& Technology, Lahore, Pakistan \\ Corresponding author: siddaysha27@gmail.com,nimijutt729@gmail.com, chamdadalijutt786@gmail.com
}

(Received, $14^{\text {th }}$ November 2020, Revised $21^{\text {th }}$ June 2021, Published $24^{\text {th }}$ June 2021)

\begin{abstract}
The higher hydrostatic pressure has been found as a high potential technique to safe microbiologically or protects and enhance the shelf life of foodstuffs. Microorganisms showed have different behavior under different types of high-pressure conditions. The higher pressure only can't kill microbes because of the formation of highly stable or solid spores around bacterial cells; there is the use of synthetization therapy, pasteurization, sterilization under higher pressure and heat. The viruses showed fewer resistance against higher pressure and heat as compared to spores of bacteria which are much resistant than viruses. It can be abolished without eradicating contagion. The power detected antibodies leads to the chance of a vaccine creation. Depending on such factors, their reaction to pressure types is strain, operating climate, and substrate. The ability of what are the causes connect are needed to select optimal one food processing conditions.
\end{abstract}

Keywords: pressure, microbes, pasteurization, sterilization, bacterial spores

\section{Introduction}

During $21^{\text {st }}$ century, the customers have access for good quality food, fresh or clean dishes and nice taste without any microbial additives with a safe and long life. There is a technology in food sciences which has the ability to accommodate these questions known as maximum or higher pressure operation (de Almeida et al., 2006; Xu et al., 2017). Processing high pressure called maximum hydrostatic pressure or maximum pressure. The technique which uses maximum pressures to kill microorganisms on 900 $\mathrm{MPa}$ however, the microbes still again produced in our food at even room temperature due to the presence of microbial spores in food stuffs (Aguilera et al., 2009; Chávez-Murillo et al., 2001). In food processing the proceeding pressure is equivalent to a weight of $500 \mathrm{Mpa}$. Then maximum pressure is used for storage of food like after the treatment of milk with higher pressure and preservatives, the milk remained sweet or tasteful for a long time (Papathanasiou et al., 2015; Lafarga et al., 2019).

\section{Maximum Pressure Preparation Equipment}

Packages of food are charged in the containers, topped closed and pumped pressure fluid from the bottom of the dish. The isostatic method uses as high pressure. The higher pressure helped to penetrate the heat in food with equal proportions throughout the food either it is liquid, soil or semisolid food materials.

\section{Important Pressure Effects in Cells of Microbes}

Many studies have revealed that the high pressure treating changes, including whole cells, especially the cell membranes of microbes, morphology of cell, effects on enzymes and mechanisms of genetic, including proteins of microorganisms all are affected and caused the death of microbes (Mustafa et al., 2018; Shim et al., 2018). The cell membranes of microbes are usually damaged due to high pressure and temperature conditions. These changes combined natural agitation cell contain anatomy, osmosis loss reactivity and loss RNA with amino acid in extracellular environment. As a result, the membrane loses function described under pressure treatment. Lactobacillus, when treated with a pressure of 250 MPa decreased ATPase action and caused reduction of microbial activities even death. High pressure has little effect on the cell wall and morphological changes in general by demonstration under a light microscope discovered in the prokaryotes and lower eukaryotes. Anyhow, it can cause spoil inside the cell which can be seen with the help of electron microscopy. When using scanning electron microscopy Listeria monocytogenes have sprouted scars on the cell surface (Stantiall et al., 2018; Ahmad et al., 2016; Deng et al., 2014).

Reaction Effect of Pressure with Biochemical High pressure promotes biochemical reactions it can slow down or lag, but caused a reduction in quantity reactions that lead to enhance in quantity. Most biochemical reactions leads to changes in volume and 
are so affected under pressure. Research on volume change showed that proteins are the big missions stress. Some of the enzymes example bacillus subtilis alpha-amylase showed resistance. While a pressure of $500 \mathrm{MPa}$ and $200 \mathrm{MPa}$ don't activate much faster as temperature can. Covalent bonds usually do not affect the pressure applied in proceeding of food. Because of the flavor components and vitamins, high levels are not eliminated predominant (Famelart et al., 1998; Meurer et al., 2020).

\section{Effect on genetics}

Nucleic acids are resistant to relatively high pressures. The composition of the DNA helix often showed stability under various conditions. The formation of hydrogen bonds remained fixed. The activation of various endonuclease enzymes are affected because of higher pressure which may cause damages in the DNA. Maximum pressure does not allow activating microorganisms in processed foods (Alsalman et al., 2020; Yang et al., 2017).

\section{Injure Of Pressure}

Inactivating the microorganisms can instead damage some of the probiotic bacterial population. Injured cells can be repaired depending on the conditions after treatment.

\section{Endospores of bacteria}

Microorganisms respond variously to pressure. Very resistant can be bacterial endospores. Even under very high pressure conditions, radiation and temperature these bacterial cells remained alive. There may be important changes between the spores among species as well as strains of the similar species. In general, there is large number gram +ve bacteria which showed hindrance than gram -ve like the cocci are most hinder than rod like bacteria. The reason is the structure of the cell membrane which is assumed to be larger. By pressure gram-negative bacteria make it sensitive changes in the environment caused (Marefati et al., 2017; Saari et al., 2018).

\section{Prions \& Viruses}

There is similarly less information about the ineffectiveness of pressure on number of viruses as compared to other microorganisms. In case of polio virus, the cultural environment seems to be relatively stable at a temperature of $21^{\circ} \mathrm{C}$ for 5 minutes at 450 $\mathrm{MPa}$ does not reduce the formation of plaques unit. The same treatment conditions as a result of hepatitis A, is seemed as lowered to an invisible level. However, sea water treatment has enhanced the emphasis. Hepatitis is treated in a culture medium as there are also reports of relative susceptibility to HIV-1 (Hebishy et al., 2015; Villamonte et al., 2016). The resulting 400-600 MPa at a temperature of $25{ }^{\circ} \mathrm{C}$ for 10 minutes, caused to reduce viable particles in tissue culture medium. But the resistance of different strains to pressure showed variations. Foot as with oral disease virus showed sensitive to high pressures. The treated virus can also produce a neutralizing antibody production in rabbits. This shows that the results are high which can be safe, also simple, inexpensive and repetitive used for the production of viral vaccines. It has been proven that some of the high pressures may cause effects on prions as treatment of prions 60 to $700 \mathrm{MPa}$ for 2 hours, the alive scale animals increased significantly (Ashie and Simpson, 1996; Butz et al., 1996) .

\section{Moulds \& Yeasts}

Yeast is not usually associated with foodborne illness or weakness but is important in spoilage or damage, especially acidic foods. The susceptibility of the mold, however, shown to be vegetative. The spores are more stable. It is speculated that there may be pressure on pre-formed mycotoxins. The effect of treatment on covalent bonds is less because it is limited. Anyhow, research reported that the pathogen, by aspergillus, penicillium and many species produced mycotoxin in foods. Then amount of apple juice reduced 300, 500 and 1 hour of treatment 800 $\mathrm{MPa}$ at a temperature of $20^{\circ} \mathrm{C}$ (Casadei et al., 2002; Alsalman et al., 2020; Yang et al., 2017).

\section{Substrate Effect}

Substrate is an important factor for storage of food materials through use of higher pressure and temperature conditions. Like make up a specific food Proteins, carbohydrates and lipids can be protected through use of higher pressure. For example, the pressure resistant strain gave not activation like $E$. coli in food substrate. When pressure is applied, the $\mathrm{pH}$ returns to its initial state. The significance, however, of these unexpected changes are unknown. Along with the effect of $\mathrm{pH}$, predominantly it affects the life of microbes (Alsalman et al., 2020; Yang et al., 2017).

\section{Temperature Effect}

Temperature can be significant in the treatment of pressure. As discussed, high-pressure sterilization helps to achieve preservation for long time. The higher pressure is also recommended for overcoming the problem of depression hinder strains cells. Many scientists reported that about temperature effect which do not allow to activate E. coli in poultry as well as in milk under $400 \mathrm{MPa}$ at $50^{\circ} \mathrm{C}$ for 15 minutes. The temperature of the refrigerator may enhance pressure not activity. Reported that sheep's milk, at a heat of $40^{\circ} \mathrm{C}$, pressure of $15-450 \mathrm{MPa}$ was effective for 25 days as compared to low affective at $50^{\circ} \mathrm{C}$ (Alsalman et al., 2020; Stantiall et al., 2018; Ahmad et al., 2016; Deng et al., 2014).

Pressure Cure Microbiological Standard Foods for Improvement:

[Citation: Ali, I., Idrees, N., Siddque, A., Shah, K.H., Ahmad, R., Ali, A., Fateh, A. (2021). Microbial composition of processed foods. Biol. Clin. Sci. Res. J., 2021: 74. doi: https://doi.org/10.54112/bcsrj.v2021i1.74] 
Jams and sauces of food were forcibly refined and initially sold market presence in the recently 1990 . To cure jams of fruit surround $400 \mathrm{MPa}$ for $5 \mathrm{~min}$ in the room heat notably less down the number of microorganisms, especially yeast \& mold. Juices of fruit are generally proceeded at $400 \mathrm{MPa}$ or above a few minutes at a temperature $20^{\circ} \mathrm{C}$ or less. This can be critical decrease in the number of mold \& yeasts and increase shelf life. In the US foods are guacamole. Its commercial keeps up foundation on growth \& consumer preferences. For a new flavor of guacamole developed in way contrasted to temperature cured or frozen creates. To treat a capacity of five hundred in two minutes is enough to enhance the main shelf life (Alsalman et al., 2020; Stantiall et al., 2018; Ahmad et al., 2016; Deng et al., 2014). Afterward packaging treatment with high pressure for example last storage part, provide extra guarantee of microbial protection. Packages consist of pressed fried chicken, meat, guacamole, and onions are also used in USA. Products shelf life of the refrigerator should be at least 30days as should be heated in a microwave oven before consumption.

\section{Conclusion}

High productivity of microbial food protects and increase the shelf life by high hydrostatic pressure. Micro-organisms undergo different reactions under high pressure. Its primary application is to produce processed food. The techniques of producing processed food in high pressure are proved to be beneficial. The other great advantage of this method is that it can also be used to process not only solid food but also liquids. The food produced has a lot of important nutritional factors. High pressure processing is an isostatic method. We can see how to increase or enhance the life it is better than other methods as it does not depend on the structure or appearance of the food resulting in complete in activation of micro-organism.

Conflict of interest

The authors declared absence of conflict of interest.

\section{References}

Aguilera, Y., Esteban, R. M., Benitez, V., Molla, E., \& Martin-Cabrejas, M. A. (2009). Starch, functional properties, and microstructural characteristics in chickpea and lentil as affected by thermal processing. Journal of agricultural and food chemistry, 57(22), 10682-10688.

Ahmed, J., Thomas, L., Taher, A., \& Joseph, A. (2016). Impact of high pressure treatment on functional, rheological, pasting, and structural properties of lentil starch dispersions. Carbohydrate polymers, 152, 639647.
Alsalman, F. B., Tulbek, M., Nickerson, M., \& Ramaswamy, H. S. (2020). Evaluation and optimization of functional and antinutritional properties of aquafaba. Legume Science, 2(2), e30.

Ashie, I. N. A., \& Simpson, B. K. (1996). Application of high hydrostatic pressure to control enzyme related fresh seafood texture deterioration. Food Research International, 29(5-6), 569-575.

Butz, P., Funtenberger, S., Haberditzl, T., \& Tauscher, B. (1996). High Pressure Inactivation ofByssochlamys niveaAscospores and Other Heat Resistant Moulds. LWT-Food Science and Technology, 29(5-6), 404-410.

de Almeida, Costa, G.E., Silva, Queiroz-Monici, K., Reis, S.M.P.M., de Oliveira, A.C. (2006). Chemical Composition, Dietary Fibre andResistant Starch Contents of Raw and Cooked Pea, Common Bean, Chickpea and Lentil Legumes. Food Chemistry. 94, 327330.

Casadei, M. A., Manas, P., Niven, G., Needs, E., \& Mackey, B. M. (2002). Role of membrane fluidity in pressure resistance of Escherichia coli NCTC 8164. Applied and Environmental Microbiology, 68(12), 5965-5972.

Chávez-Murillo, C. E., Veyna-Torres, J. I., CavazosTamez, L. M., de la Rosa-Millán, J., \& SernaSaldívar, S. O. (2018). Physicochemical characteristics, ATR-FTIR molecular interactions and in vitro starch and protein digestion of thermally-treated whole pulse flours. Food Research International, 105, 371383.

Deng, Y., Jin, Y., Luo, Y., Zhong, Y., Yue, J., Song, X., \& Zhao, Y. (2014). Impact of continuous or cycle high hydrostatic pressure on the ultrastructure and digestibility of rice starch granules. Journal of Cereal Science, 60(2), 302-310.

Famelart, M. H., Chapron, L., Piot, M., Brulé, G., \& Durier, C. (1998). High pressure-induced gel formation of milk and whey concentrates. Journal of Food Engineering, 36(2), 149-164.

Hebishy, E., Buffa, M., Guamis, B., Blasco-Moreno, A., \& Trujillo, A. J. (2015). Physical and oxidative stability of whey protein oil-in-water emulsions produced by conventional and ultra high-pressure homogenization: Effects of pressure and protein concentration on emulsion characteristics. Innovative Food Science \& Emerging Technologies, 32, 79-90.

[Citation: Ali, I., Idrees, N., Siddque, A., Shah, K.H., Ahmad, R., Ali, A., Fateh, A. (2021). Microbial composition of processed foods. Biol. Clin. Sci. Res. J., 2021: 74. doi: https://doi.org/10.54112/bcsrj.v2021i1.74] 
Klamczynska, B., Czuchajowska, Z., \& Baik, B. K. (2001). Composition, soaking, cooking properties and thermal characteristics of starch of chickpeas, wrinkled peas and smooth peas. International journal of food science \& technology, 36(5), 563-572.

Lafarga, T., Villaró, S., Bobo, G., \& Aguiló-Aguayo, I. (2019). Optimisation of the $\mathrm{pH}$ and boiling conditions needed to obtain improved foaming and emulsifying properties of chickpea aquafaba using a response surface methodology. International Journal of Gastronomy and Food Science, 18, 100177.

Marefati, A., Wiege, B., Haase, N. U., Matos, M., \& Rayner, M. (2017). Pickering emulsifiers based on hydrophobically modified small granular starches-Part I: Manufacturing and physico-chemical characterization. Carbohydrate Polymers, 175, 473-483.

Meurer, M. C., de Souza, D., \& Marczak, L. D. F. (2020). Effects of ultrasound on technological properties of chickpea cooking water (aquafaba). Journal of Food Engineering, 265, 109688.

Mustafa, R., He, Y., Shim, Y. Y., \& Reaney, M. J. (2018). Aquafaba, wastewater from chickpea canning, functions as an egg replacer in sponge cake. International journal of food science \& technology, 53(10), 2247-2255.

Papathanasiou, M. M., Reineke, K., Gogou, E., Taoukis, P. S., \& Knorr, D. (2015). Impact of high pressure treatment on the available glucose content of various starch types: a case study on wheat, tapioca, potato, corn, waxy corn and resistant starch (RS3). Innovative Food Science \& Emerging Technologies, 30, 24-30.

Saari, H., Johansson, D. B., Knopp, N., Sjöö, M., Rayner, M., \& Wahlgren, M. (2018). Pickering emulsions based on $\mathrm{CaCl} 2$-gelatinized oat starch. Food Hydrocolloids, 82, 288-295.

Shevkani, K., Singh, N., Chen, Y., Kaur, A., Yu, L. (2019). Pulse Proteins: Secondary Structure, Functionality and Applications. Journal Food Science and Technology, 56, 2787-2798.

Shim, Y. Y., Mustafa, R., Shen, J., Ratanapariyanuch, K., \& Reaney, M. J. (2018). Composition and properties of aquafaba: Water recovered from commercially canned chickpeas. JoVE (Journal of Visualized Experiments), (132), e56305.

Stantiall, S. E., Dale, K. J., Calizo, F. S., \& Serventi, L. (2018). Application of pulses cooking water as functional ingredients: the foaming and gelling abilities. European Food Research and Technology, 244(1), 97-104.

Villamonte, G., Jury, V., \& de Lamballerie, M. (2016). Stabilizing emulsions using highpressure-treated corn starch. Food Hydrocolloids, 52, 581-589.

Xu, Y., Obielodan, M., Sismour, E., Arnett, A., Alzahrani, S., \& Zhang, B. (2017). Physicochemical, functional, thermal and structural properties of isolated Kabuli chickpea proteins as affected by processing approaches. International Journal of Food Science \& Technology, 52(5), 1147-1154.

Yang, Y., Fang, Z., Chen, X., Zhang, W., Xie, Y., Chen, Y., ... \& Yuan, W. (2017). An overview of Pickering emulsions: solid-particle materials, classification, morphology, and applications. Frontiers in Pharmacology, 8, 287.

\section{(2) $(1) \Theta$}

Open Access This article is licensed under a Creative Commons Attribution 4.0 International License, which permits use, sharing, adaptation, distribution and reproduction in any medium or format, as long as you give appropriate credit to the original author(s) and the source, provide a link to the Creative Commons licence, and indicate if changes were made. The images or other third party material in this article are included in the article's Creative Commons licence, unless indicated otherwise in a credit line to the material. If material is not included in the article's Creative Commons licence and your intended use is not permitted by statutory regulation or exceeds the permitted use, you will need to obtain permission directly from the copyright holder. To view a copy of this licence, visit http://creativecommons.org/licen ses/by/4.0/.

(C) The Author(s) 2021

[Citation: Ali, I., Idrees, N., Siddque, A., Shah, K.H., Ahmad, R., Ali, A., Fateh, A. (2021). Microbial composition of processed foods. Biol. Clin. Sci. Res. J., 2021: 74. doi: https://doi.org/10.54112/bcsrj.v2021i1.74] 